\title{
Obituaries
}

\section{Arthur Williams}

Physician who played a major part in the development of medicine and medical training in east Africa

Arthur Williams' influence in east Africa began in 1931 when, after medical training at Cambridge and Westminster Hospital, he joined the Colonial Medical Service and was posted to Uganda. Early up-country posts as a medical officer were followed by work in Mulago Hospital, Kampala, where he developed an increasing interest in medical education, then at its early stages, and he was appointed lecturer in medicine and therapeutics. At the outbreak of the second world war he was accepted for naval service but not released by the Ugandan government, continuing to work at Mulago as medical officer and lecturer in physiology.

An interest in cardiac disease and hypertension continued throughout his life, and during the war years he was also involved in pulmonary tuberculosis, starting the first clinics for collapse therapy. He was a member of the editorial panel of the East African Medical Journal.

A two year spell in neighbouring Tanganyika followed, as physician to the government hospital in Dar es Salaam, before a return to Uganda in 1949 with his appointment as medical superintendent and physician to Mulago Hospital. With a pathologist colleague he pursued research into the curious condition of endomyocardial fibrosis, a significant cardiac disease in Uganda, of unknown aetiology. He helped initiate the scheme for the building of the new 900 bed teaching hospital at Mulago, and was subsequently closely involved with its planning.

In 1951 he was appointed head of the department of medicine at Makerere University College and two years later became the first professor of medicine. Concurrent posts during the next decade included membership of the Uganda Medical Board, consultant physician to the Ugandan government, and membership of the council of the University College of East Africa. $\mathrm{He}$ was largely responsible for initiating and organising the Medical Research Council's east African tuberculosis chemotherapy trials.

He was a founder member and president of the Association of Physicians of East Africa in 1957 and in the same year became

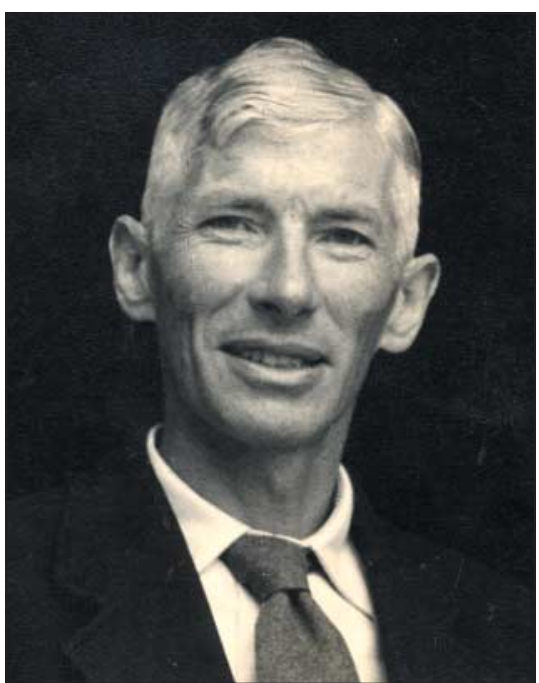

often thickly forested. The lake hippos were benign, often just a couple lazing in a bay during the daytime, their nocturnal foraging ashore preceded by much grunting, which the younger Williamses learned to mimic. Although crocodiles were fairly common in those days they tended to be nocturnal fish eaters and spent their days sunning on off-lying rocks, sometimes disturbed by a mischievous airgun pellet that would bounce harmlessly off their thick hides.

In 1961, after 30 years' service to medicine in Uganda, Arthur was awarded the $\mathrm{CBE}$, and he returned to England to take up the new post of director of postgraduate medical studies at the University of Oxford. Other appointments held during this time included secretary of the medical school, chairman of the board of the faculty of medicine, vice chairman of the Nuffield Committee for Research and Postgraduate Medical Training, and member of the board of governors, United Oxford Hospitals. He was a founder fellow of St Cross College. Early in his time at Oxford he was a member of a committee appointed to advise the government of Tanganyika on the future of its health services, and for several years was a member of an advisory committee on low priced books for developing countries.

He finally retired in 1971, returning to Northumberland. Later years were spent in Suffolk and then Cumbria, where he kept busy with his continuing interests in ornithology and botany, and his hobby of book binding.

At the time of his 100th birthday he had 11 grandchildren and 16 great grandchildren. He died five days after his birthday. [M J Williams]

Arthur Williams, physician, and professor of medicine, Makerere University College, Uganda, 1953-61 (b 1905; q Westminster Hospital, London, 1929; CBE, MA, MD, FRCP), $d 2$ September 2005. his life, and with a sailing dinghy he and the family were able to explore the northern shores and islands of the huge freshwater expanse of Lake Victoria, many of the islands being uninhabited at that time and
Longer versions of these obituaries are available on bmj.com 


\section{Samuel Hillman}

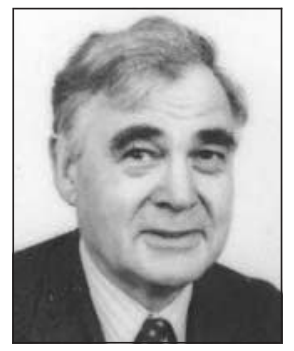

Former general practitioner Liverpool (b Glasgow 1923; q Glasgow 1945), died from pneumonia secondary to metastatic prostate cancer on 14 September 2005.

Samuel Hillman worked in partnership with his wife for 38 years; they were affectionately known as Dr Sam and Dr June to patients. After qualification Samuel was a flight lieutenant in the Royal Air Force for three years. He then held surgical registrar posts at the Glasgow Royal Infirmary and Whipps Cross Hospital, London, before settling into family practice in Liverpool. He was also the clinical assistant to the accident and emergency department at Walton Hospital for 10 years, student health doctor to a teacher training college for over 30 years, and medical adviser to Jacob's biscuits. He leaves June, two sons, and four grandchildren. [JonAthan Hillman]

\section{Archibald Stewart McCallum Lamont}

Former director of anaesthesia Royal Hobart Hospital, Tasmania (b Glasgow 1926; q Glasgow 1949; FFA RCS), d 27 August 2005.

Steward Lamont became interested in anaesthesia soon after graduating, and did his national service in the Royal Air Force in Iraq as an anaesthetist. He was a consultant in Leeds before being appointed director of anaesthesia at the Royal Hobart Hospital, Tasmania, in 1977. This was a time when there was a certain amount of upheaval in the Australian medical world. Medibank was being introduced, and several anaesthetists had resigned from the hospital. Stewart's first tasks were to stabilise the department and to encourage trainees to join. Eventually, a programme for junior staff was organised and sufficient registrars obtained their fellowship. He leaves a wife, Hanna, and a daughter. [ROSANNE LAMONT]

\section{Desmond Martin}

Former general practitioner Forest Row, East Sussex (b 1942; q Glasgow 1967; MRCGP,DA, DObst RCOG), died from cancer of the caecum on 3 October 2005.

After qualification Des served a short service commission in the Royal Navy, making many lifelong friendships during his time in the Nuclear Submarine Service. He entered general practice in Forest Row in 1974 and had 27 years in the Ashdown Forest Practice until retirement in 2001, which was enriched by time to enjoy gardening, golfing, local history, and music, especially singing in choirs. He leaves a wife, Lindsey; four children; and six grandchildren. [IoNA MarTin]

\section{Donald Forbes Mungall}

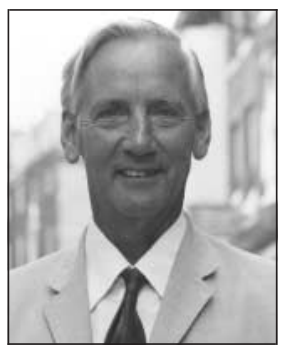

Former general practitioner York (b Carlisle 1916; q Edinburgh 1939), died from generalised cerebrovascular disease on 10 September 2005. During the second world war Don served for four years in the Royal Air Force Volunteer Reserve, mostly in the Western desert. On demobilisation he joined a long established practice in York, where he combined an enthusiasm for new developments with traditional patient centred care. $\mathrm{He}$ was medical officer to Bootham School, St John's Teacher Training College, and York Waterworks, of which he was also a director. His year as president of the York Medical Society was marked by his restoration of the society's historic rooms. He leaves a wife, Bishie; three children; and four grandchildren. [IAN MungaLL]

\section{Jane Munks (née Sweatman)}

Senior clinical medical officer in family planning North Cornwall 1963-93 (b Dorking 1930; q King's College Hospital, London, 1954), died from multiple myeloma on 6 September 2005.

After qualifying and house jobs at King's Jane devoted her life to her family and husband, Arthur. Jane and Arthur moved to Bude in 1961 and Jane worked for the Department of Health and Social Security and as a locum in a local general practice before taking over the family planning in North Cornwall. This she developed into an active service for all ages. Jane was president of the local branch of the MS Society and a keen gardener. She leaves Arthur, four children, and seven grandchildren. [BILL Munks]

\section{Raymond Ernest Willis Oliver}

Former general practitioner Ealing, London (b 1917; q Middlesex Hospital, London, 1940; DIH, FRCGP), d 12 February 2005.

Ray served in the Royal Air Force during the second world war and then went into partnership with an old school friend. He also developed a keen interest in industrial medicine. For over 25 years he worked for the Lucas Medical Service and was, at various

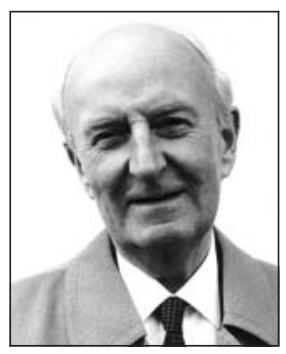

times, responsible for 17 different factories. Active in local medical politics, he was made a fellow of the BMA and originated the idea of an annual fellows dinner. He was married to Hilda for 63 years, and leaves two sons and five grandchildren. [STEPHEN Oliver]

\section{Eric William ("Bill”) John Townsend}

Former general practitioner East Molesey, Surrey (b 1914; q Bristol 1940), d 29 May 2005.

After qualifying Bill spent the latter years of the second world war attached to the Royal Engineers in Germany and then Palestine. In 1947 he bought a practice in East Molesey, where he remained singlehanded throughout his career until 1980 . He was a keen dinghy sailor and his garden was his pride and joy. He retired to Shaldon in South Devon. He leaves his second wife, Suzanne, their two children, and four children from his first marriage. [DAVID TownsEND]

\section{Donald Easton Wright}

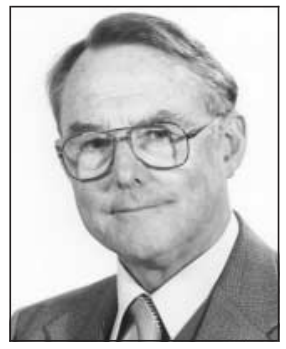

Former senior lecturer in histology Newcastle upon Tyne (b Nottingham 1920; q London 1946; PhD), died from pneumonia associated with dementia on 15 April 2005.

Donald's medical studies were interrupted by the second world war, during which he worked for the forensic science service in Cardiff. After the war he completed his education, moving to the medical school at Newcastle upon Tyne, then part of the University of Durham, in 1947 as lecturer in physiology. He became senior lecturer in histology from 1951. Generations of students knew him affectionately as "Cheesy Wright." After his retirement in 1982 he further developed a lifelong interest in the church organ, becoming an expert with a national and international reputation in church organ design. He leaves a wife, Margaret; three sons; and five grandchildren. [Peter Wright] 